\title{
The Philosophy of Existentialism: Individual Awareness in Indonesian Education
}

\author{
ADITYA YOGA PURNAMA ${ }^{1}$, AGNESI SEKARSARI PUTRI ${ }^{2}$, RAGIL SAPUTRI ${ }^{3}$ \\ ${ }^{1}$ Universitas Sarjanawiyata Tamansiswa, Jalan Batikan UH.III/ 1043, Yogyakarta, Indonesia \\ adityayoga@ustjogja.ac.id \\ 2Universitas Negeri Yogyakarta, Jl. Colombo No. 1, Sleman, Yogyakarta, Indonesia \\ agnesi.sekar@gmail.com \\ ${ }^{3}$ Universitas Sarjanawiyata Tamansiswa, Jalan Batikan UH.III/ 1043, Yogyakarta, Indonesia \\ ragilsaputri@gmail.com
}

\begin{abstract}
The philosophy of existentialism emerged driven by the uncertain world conditions due to world wars. So existentialism is present as a thought movement that emphasizes human subjectivity and freedom. This study has a purpose for reflection. Reflection means the process of understanding events in the mind or experience that is owned. This study uses descriptive qualitative research. This study utilizes a literature search. The literature search process begins with key phrases such as "existentialism", "education" and "awareness". Man must exist, which means realizing that he exists to control himself and act on his behalf. The philosophy of existentialism talks about human existence, while talking about humans means questioning educational issues. Each person is unique, which is different from one another. Realizing this is important for students, parents, teachers, principals, board members, and all those involved in education. Education is expected to realize the "intensity of awareness" of students. So that they are aware of their responsibility to determine the life they will live themselves.
\end{abstract}

Keywords: existentialism, education, awareness 


\title{
Filsafat Eksistensialisme: Kesadaran Individu dalam Pendidikan Indonesia
}

\begin{abstract}
Abstrak
Filsafat eksistensialisme muncul didorong oleh keadaan dunia yang tidak menentu akibat perang dunia. Sehingga eksistensialisme hadir sebagai gerakan pemikiran yang menonjolkan subjektifitas dan kebebasan manusia. Studi ini memiliki tujuan untuk refleksi. Refleksi berarti proses memahami peristiwa dalam pikiran atau pengalaman yang dimiliki. Studi ini menggunakan penelitian deskriptif kualitatif. Studi ini memanfaatkan pencarian literatur. Proses pencarian literatur dimulai frasa kunci seperti "eksistensialisme", "pendidikan" dan "kesadaran". Manusia harus eksis yang artinya menyadari bahwa dia ada untuk menguasai dirinya dan bertindak atas nama dirinya. Filsafat eksistensialisme berbicara tentang keberadaan manusia, sedangkan berbicara tentang manusia berarti mempersoalkan masalah pendidikan. Setiap pribadi adalah unik yakni berbeda-beda satu dengan yang lainnya. Menyadari hal tersebut menjadi penting bagi seorang siswa, orangtua, guru, kepala sekolah, anggota dewan, dan semua yang terlibat didalam pendidikan. Pendidikan diharapkan dapat mewujudkan "intensitas kesadaran" siswa. Sehingga sadar akan tanggungjawabnya untuk menentukan kehidupan yang akan dijalaninya sendiri.
\end{abstract}

Kata kunci: eksistensialisme, pendidikan, kesadaran

\section{PENDAHULUAN}

Di era 4.0 yang menjadi topik adalah teknologi seperti big data dan artificial intellegence. Akibat perubahan era teknologi ini banyak pekerjaan yang sebelumnya ada menjadi hilang dan muncul pekerjaan baru. Namun, dalam era ini kita sering melupakan bahwa individu adalah unik yang berbeda-beda dalam memahami tentang dunia, gagasan yang baik dan buruk dan bagaimana seseorang harus menjalani hidupnya. Setiap individu berbeda satu sama lainnya (Kirillova, 2019). Sejarah munculnya filsafat eksistensialisme ini didorong oleh keadaan dunia yang tidak menentu akibat perang dunia. Rasa takut terhadap ancaman perang menimbulkan kegelisahan. Manusia menjadi pribadi yang eksistensinya terancam oleh perbuatannya sendiri. Sehingga eksistensialisme hadir sebagai gerakan pemikiran yang menonjolkan subjektifitas dan kebebasan manusia terutama di Indonesia (Tambunan, 2016). Pengalaman subjektivitas ini penting dalam filsafat eksistensialisme sedangkan kebebasan muncul didalam gaya hidup baru seperti sekarang. Gaya hidup baru muncul seperti budaya vlogger dengan memiliki channel youtube sendiri sehingga bebas berekspresi. Kini berbicara di depan 
kamera bebas berbicara, bebas memberi edukasi, bebas berpendapat bisa meraup uang banyak yang didapatkan dari adsense misalnya.

Filsafat eksistensialisme sebenarnya berpusat pada realitas dan keberadaan manusia berdasarkan filsuf jerman seperti Karl Jaspers dan Martin Heidegger (Gray, 1951). Kedua tokoh ini menekankan pembahasan kematian lebih dari Kiergard, Sartre, dan tokoh lain dari aliran ini. Pertanyaan-pertanyaan mengenai kematian seperti fakta manusia harus mati dan bagaimana menganggap kematian sebagai peristiwa dimasa depan dapat dibahas merujuk kedua tokoh tersebut. Eksistensialisme sebagai filosofi yang lahir dari penolakan Kierkegaard terhadap idealisme Hegel (Clemence, 1967). Sejarah pemikiran eksistensial dapat ditelusuri melalui beberapa tokoh seperti Gabriel Marcel, Heidegger, Kierkegaard, Camus, Friedrich Nietzsche, Jean Paul Sartre. Filsafat eksistensialisme memiliki sudut pandang anti esensialisme. Sudut pandang anti esensialisme tidak mengarah pada pragmatism, instrumentalism, atau konvensionalism (Ginev, 2014).

Ajaran eksistensialisme sebenarnya sangat beragam jika dilihat dari berbagai latarbelakang filsuf. Seperti Gabriel Marcel yang berdasarkan atas kesetiaan, harapan, cinta dan selalu melibatkan tuhan dalam pemikirannya. Soren Kierkegaard menerangkan bahwa yang terpenting adalah bagaimana hidup, membuat pilihan dan mengambil keputusan yang benar. Nietzche seorang filsuf yang menyambut datangnya zaman tuhan tidak ada lagi atau sudah mati. Sedangkan Sartre memiliki keyakinan bahwa segala sesuatu bisa dimaknai setelah segala sesuatu ada terlebih dahulu. Namun dari berbagai pemikiran filsuf tersebut ada substansi aliran eksistensialisme yaitu pertama, motif pokonya adalah cara manusia berada atau eksis. Kedua, bereksistensi diartikan secara dinamis atau aktif menciptakan dirinya. Ketiga, memberikan tekanan yang sangat besar terhadap pengalaman eksistensial.

\section{Eksistensialisme Jean Paul Sartre}

Dalam tulisan populernya, Jean Paul Sartre memberikan premis dasar eksistensialisme yaitu "Eksistensi mendahului esensi". Di salah satu tulisannya yang berjudul "Existentialism is a Humanism". Maksud dari eksistensi mendahului esensi menurut Sartre adalah manusia ada atau eksis terlebih dahulu, kemudian dalam hidupnya dia memberikan makna atau esensi terhadap kehidupannya. Berbeda dengan benda seperti pisau yang esensinya ada karena keberadaan manusia artinya esensi dahulu kemudian eksis (Atwell, 1969). Berarti manusia ditempatkan pada posisi sebagai pembuat esensinya. Dengan kata lain, benda-benda di alam semesta tidak akan bermakna atau tidak memiliki tujuan apa 
apa jika terpisah dari manusia. Dunia ini bermakna karena manusia. Manusia memberikan nama segala sesuatu yang ada seperti nama matahari, bulan, meja, kursi dan sebagainya itu semua adalah istilah yang diberikan oleh manusia.

\section{Ontologi Jean Paul Sartre}

Dasar ontologi Sartre dikaitakan dengan gurunya yaitu Heidegger. Maka terkait dengan Husserl dan Hegel. Husserl mempengaruhi pikiran Heidegger yang dapat dilihat berdasarkan pendekatan phenomenologis yan memperhatikan keberadaan manusia (Muzairi, 2002). Kata "ada" dari Sartre pada dasarnya berasal dari Heidegger, kemudian dilengkapi ajaran tentang "ada". Ontologi Sartre menyinggung tulisan Descartes "Aku berpikir oleh karena itu aku ada". Ontologi Sartre diberikan pengertian sebagai berikut: studi tentang struktur yang ada dari yang mengada diambil sebagai totalitas. Ini berarti menggambarkan bagaimana kesadaran kehadiran manusia di dunia. Oleh karena itu, studi ini memiliki tujuan untuk refleksi. Refleksi berarti proses memahami peristiwa dalam pikiran atau pengalaman yang dimiliki.

\section{METODE PENELITIAN}

Studi ini digunakan untuk refleksi dalam membangun pendidikan. Pencarian literatur di berbagai negara dilakukan sebagai pendukung studi. Hanya studi yang berhubungan dengan peristiwa pendidikan, filsafat, dan refleksi yang dimasukkan dalam tinjauan ini. Studi ini menggunakan jenis penelitian kualitatif deskriptif. Penulisan studi ini menggunakan metode pengumpulan data berupa studi kepustakaan dengan mengumpulkan jurnal, buku dan artikel ilmiah yang sesuai pembahasan tentang aliran filsafat eksistensialisme

\section{HASIL DAN PEMBAHASAN}

Secara umum eksistensialisme dipandang sebagai protes terhadap metafisika tradisional, mekanisasi manusia, dan nilai-nilai budaya kontemporer (Rumianowska, 2020). Pemikiran eksistensial juga sering digunakan dalam praktek debat dalam berbagai bidang di luar filsafat, seperti kesehatan mental, keperawatan, pendidikan, etika bisnis, perilaku organisasi dan penelitian (Lawler, 2005). Pemikiran eksistensialisme juga mempengaruhi tokoh bangsa Indonesia (Tambunan, 2016). Driyarkara adalah salah satu tokoh yang pemikirannya dipengaruhi oleh filsafat eksistensialisme. Oleh sebab itu, pengaruh eksistensialisme pada dunia pendidikan Indonesia sangat besar. Kita tahu bahwa Driyarkara merupakan tokoh pelopor berdirinya kampus yang sekarang dikenal 
sebagai Universitas Sanata Dharma. Selain itu ada seorang tokoh pendidikan bangsa Indonesia lain yaitu Ki Hajar Dewantara dengan tulisannya yang berjudul "seandainya aku seorang belanda". Tulisan tersebut salah satu bentuk sadar terhadap kebebasan mengemukakan pendapatnya. Sehingga dimungkinkan bahwa aliran eksistensialisme mempengaruhi pergerakan kebebasan di Indonesia terutama dalam masa menuju kemerdekaan.

Menurut eksistensialis, cara hidup yang baik tidak melalui tradisi sosial atau adat istiadat setempat (G.M. Malik, Akhter, 2013). Melainkan cara hidup yang segala keputusannya hasil pertimbangannya sendiri bukan orang lain. Sering kita menjawab sebuah pertanyaan dengan mengacu jawaban orang lain, ini menunjukkan bahwa kita tidak otentik. Manusia harus eksis yang artinya menyadari bahwa dia ada untuk menguasai dirinya dan bertindak atas nama dirinya. Namun disisi lain harus dapat mempertanggungjawabkan apa yang telah dia pilih atau lakukan. Filsafat Filsafat eksistensialisme didasarkan atas pernyataan bahwa manusia menyadari keberadaannya, eksistensinya, serta makna keberadaannya (Vincent Martin, 2001).

\section{Eksistensialisme dan Pendidikan}

Filsafat eksistensialisme berbicara tentang keberadaan manusia sedangkan berbicara tentang manusia berarti mempersoalkan masalah kependidikan. Hidup manusia adalah tentang pendidikan. Hidup dan belajar tidak pernah terpisahkan. Sampai saat ini Pendidikan masih dipersoalkan dan masih bertumbuh secara dinamis. Kemudian menjadi pertanyaan sampai mana pendidikan Indonesia saat ini. Masih banyak fenomena sosial seperti membuang sampah sembarangan dan maraknya ujaran kebencian di dunia maya karena efek kabar palsu atau HOAX (Aprinta B, Syamsiah and Hernofika, 2017;Septanto, 2018). Berkembangnya teknologi informasi berpengaruh terhadap gaya hidup baru masyarakat yang bebas. Bebas mengakses internet, bebas berpendapat, bebas memilih mana yang benar dan yang salah. Eksistensialisme memang mengajarkan kebebasan dalam arti sebenarnya, bebas menciptakan masa depannya dan karena itu manusia sendiri yang bertanggung jawab terhadap dirinya sendiri dan orang lain. Sebenarnya dalam eksistensialisme bukannya tidak mengetahui mana yang benar dan mana yang salah akan tetapi seorang eksistensialis menganggap bahwa kebenaran bersifat relatif. Oleh karenanya, individu bebas menentukan sesuatu yang menurutnya benar. Setiap orang mengalami perasaan bebas sekaligus sedih. Ada rasa takut atas keputusan yang dipilih oleh karena itu Sartre mengingatkan bahwa kita harus berbuat tanpa berharap (Vincent, 2001). 
Dalam era teknologi saat ini, sifat manusia menjadi pesimistik. Takut tidak mendapatkan bagian dan takut kelaparan ini kita bandingkan dengan zaman dahulu, kehidupan manusia begitu sederhana, dalam menentukan suatu tujuan, sikap dan perilaku (Suhartono, 2009). Dengan demikian era industri membuat kehidupan manusia berubah menjadi penuh "persaingan" baik didalam pekerjaan maupun didalam sekolah. Sistem peringkat yang terdapat di sekolah menyebabkan kehidupan siswa menjadi terbebani, stress, penuh tekanan. Tidak hanya siswa melainkan guru, kepala sekolah dan komunitas yang terkait dengan pendidikan. Bukankah setiap pribadi adalah unik yakni berbeda-beda satu dengan yang lainnya. Menyadari hal tersebut menjadi penting bagi seorang siswa, orangtua, guru, kepala sekolah, anggota dewan, dan semua yang terlibat didalam pendidikan. Standarisasi yang terjadi saat ini membuat sekolah menjadi tidak relevan menurut beberapa peneliti seperti yang dijelaskan dalam buku Schools That Learn (Peter Senge, 2012).

Pendidikan modern saat ini dapat menghalangi keaslian pribadi karena adanya standarisasi seperti "pabrik". Pendidik eksistensialis mengkritisi aktivitas belajar yang dipaksa harus berfikiran sama sesuai kesepakatan. Pada dasarnya anak adalah unik, yang berbeda satu dengan yang lainnya. Pada dasarnya setiap individu memiliki tujuannnya masing-masing. Namun negara dapat membantu mewujudkannya dengan cara memberikan pendidikan atas dasar "intensitas kesadaran" siswa. Sadar akan tanggungjawabnya untuk menentukan kehidupan yang akan dijalaninya sendiri. Sekolah merupakan tempat perkembangan dan pemenuhan diri siswa bukan sebagai alat memperoleh pekerjaan dengan ijazahnya. Kita perlu refleksi terhadap pendidikan yang ada terutama di Indonesia. Di buku Schools That Learn dijelaskan bahwa tidak perduli semaju apa teknologi yang kita miliki, tidak perduli seberapa banyak komputer yang dimiliki, anak anak akan selalu membutuhkan tempat aman dan nyaman untuk belajar yaitu sekolah.

Dari keterangan yang telah diuraikan mengenai pandangan aliran eksistensialisme kemudian akan dianalisa. Kelebihan dan kekurangan suatu aliran selalu ada. Pandangan Sartre mengenai eksistensialisme juga tidak sepenuhnya dapat diterima, meskipun ada pandangannya yang benar. Sartre merupakan sosok atheis yang mengabaikan Tuhan. Hal ini bertentangan dengan dasar negara bangsa Indonesia yaitu Pancasila terutama disila pertama ketuhanan yang maha esa. Bertentangan dengan kompetensi inti sikap spiritual (KI 1). Kebebasan mutlak Sartre memiliki dampak yang berbahaya berhubungan dengan sifat egois dan sifat individualis. Kebebasan mutlak akan mengarah pada kesewenang-wenangan, teror https://doi.org/10.52187/rdt.v2i3.84 | 225 
dan kerusakan. Kemudian, apa yang akan terjadi jika kebebasan mutlak diterapkan di Indonesia, padahal kebebasan mutlak tidak diterapkan di Indonesia saja sudah banyak fenomena kerusakan. Namun disisi lain juga memiliki kelebihan yang dapat diajarkan kepada siswa yaitu kesadaran diri, kemandirian dan tanggungjawab terhadap pilihannya.

\section{SIMPULAN}

Pokok bahasan filsafat eksistensialisme adalah cara berada manusia di dunia (Dasein), hanya manusia yang bereksistensi. Dunia ini dimaknai oleh manusia. Filsafat eksistensialisme secara tak langsung menyebabkan manusia berpikir untuk menjadi bebas terutama dalam memilih pendidikan yang diinginkan. Tujuan pendidikan dalam eksistensialisme untuk menginspirasi individu mengenali diri sendiri, menjadi lebih reflektif, sadar diri, dan lebih manusiawi. Kelebihan dan kekurangan suatu aliran selalu ada. Kebebasan mutlak aliran eksistensialisme memiliki dampak yang berbahaya berhubungan dengan sifat egois dan sifat individualis. Disisi lain juga memiliki kelebihan yang dapat diajarkan kepada siswa yaitu kesadaran diri, kemandirian dan bertanggungjawab terhadap pilihannya. Filsafat eksistensialisme juga membangun rasa percaya diri dan kemandirian dalam hidup. Oleh karena itu, pendidikan diharapkan dapat mewujudkan "intensitas kesadaran" siswa. Sehingga sadar akan tanggungjawabnya untuk menentukan kehidupan yang akan dijalaninya sendiri.

\section{DAFTAR PUSTAKA}

Aprinta B, G. E., Syamsiah, S., \& Hernofika. (2017). Strategi Marketing Sosial

Dalam Membentuk Kesadaran Mahasiswa Membuang Sampah Pada

Tempatnya. Jurnal the Messenger, 9(2), 2017.

Atwell, J. E. (1969). Existence Precedes Essence. Man and World, 4(2), 589-591.

Clemence, M. (1967). Existentialism: A Philosophy Of Commitment. Philosophy of Science, 34(2), 103-115.

G.M. Malik, Akhter, R. (2013). Existentialism and Classroom Practice. IOSR Journal of Humanities and Social Science, 8(6), 87-91. https://doi.org/10.9790/08370868791

Ginev, D. (2014). Social practices from the viewpoint of trans-subjective existentialism. European Journal of Social Theory, 17(1), 77-94. https:/ / doi.org/10.1177/1368431013505013

Gray, J. G. (1951). The Idea of Death in Existentialism. The Journal of Philosophy, https://doi.org/10.52187/rdt.v2i3.84 | 226 
48(5), 113-127.

Kirillova, K. (2019). Existentialism and tourism: new research avenues.

International Journal of Tourism Cities, 5(3), 429-442.

https://doi.org/10.1108/IJTC-02-2019-0033

Lawler, J. (2005). The Essence of Leadership? Existentialism and Leadership. Leadership, 1(2), 215-231. https://doi.org/10.1177/1742715005051860

Rumianowska, A. (2020). Existential perspectives on education. Educational Philosophy and Theory, 52(3), 261-269.

https://doi.org/10.1080/00131857.2019.1633915

Septanto, H. (2018). Pengaruh Hoax dan Ujaran Kebencian Sebuah Cyber Crime dengan Teknologi Sederhana di Kehidupan Sosial Masyarakat. Jurnal Sains Dan Teknologi, 5(2), 157-162.

Tambunan, S. F. (2016). Kebebasan Individu Manusia Abad Dua Puluh: Filsafat Eksistensialisme Sartre. Jurnal Masyarakat \& Budaya, 18(2), 215-232.

Vincent Martin, O. P. (2001). Filsafat Eksistensialisme; Kierkegaard, Sartre, Camus. Yogyakarta: Pustaka Pelajar. 